\title{
Impact Of Covid-19 Towards Tourism Business And Sarawak Tourism's Recovery And Rebuilding Programmes: Tourism Stakeholdrs' Perspectives
}

\author{
Fency Sivadasan*, Sharzede Binti Salleh ** \\ ${ }^{*}$ Senior Manager - Research, Sarawak Tourism Board, Sarawak, Malaysia \\ ** Sharzede Binti Salleh, Chief Executive Officer, Sarawak Tourism Board, Sarawak, Malaysia \\ DOI: 10.29322/IJSRP.12.01.2022.p12106 \\ http://dx.doi.org/10.29322/IJSRP.12.01.2022.p1216
}

\begin{abstract}
This research attempts to understand the nature and intensity of Covid-19 impact towards the tourism business sector of Sarawak, the effectiveness of 3R strategy of Sarawak Tourism Board (STB) for recovery and rebuilding of tourism industry business in Sarawak and to identify the tourism industry players confidence level towards these programmes to build up the industry. Qualitative methodology was applied in this research and the data gathered from diverse set of tourism stakeholders in Sarawak through interviews. The results of the study revealed that, due to Covid-19 pandemic, Sarawak tourism business was halted due to the heavy cancellation of booked tour packages which had adversely affected the travel agents and tour operators' business. The virus impact towards the accommodation sector indicated that customer cancellations of room bookings had affected $100 \%$ impact on this sector operations. This leads to critical unemployment issues with many of the hotel staffs were jobless. The Small and Medium Enterprises (SMEs) were also gravely affected This sector received negative income due to no product sales. In addition, local SMEs who are operating in conventional ways are more affected because of lack of knowledge in e-commerce platforms to sell their products than those who had operated and have leverage the digital economy way of doing business.

Sarawak Tourism Board (STB) has taken initiatives to overcome the pandemic impact and to assist in boosting the Sarawak's Tourism Business Ecosystem (TBE). The Board has implemented the 3R strategy in 3 phases and the strategic plans involve empowering the tourism business and communities. In relation to this, STB's rebuilding and recovery phases completely focus on the revitalization of Sarawak tourism industry to spearhead the industry's recovery programmes to reach the level as in pre-COVID-19. The results of the study indicated a significant number of stakeholders showed high confidence towards STB's rebuilding and recovery initiatives. The value of this paper is its contributions to destination marketing and to provide directions for managing the pandemic crisis.
\end{abstract}

Index Terms- COVID-19 pandemic, Tourism industry stakeholders, Sarawak, impact, 3R strategy

\section{INTRODUCTION}

$\mathrm{T}$ ravel and tourism continuously have been one of the essential sectors for the people and by the people. It is a high labour-intensive industry that is able to contribute into increasing the standard of living for the people and communities it touches. It has the capacity to reduce poverty, inequality and enriches the community and society in terms of socio-economic development. According to Hubert G. Scarlett (2021), an increase in tourism sector will contribute also in agriculture and other service sectors. However, with COVID-19 pandemic, this had badly affected tourism industry globally and had shattered the sector negatively. The United Nations World Tourism Organization (UNWTO) stated that the tourist arrivals around the world declined by $73 \%$ in 2020 due to the widespread virus contamination, travel restrictions and a massive drop in travel demand. Malaysia experienced a decline of $83.4 \%$ in terms of tourist arrivals in 2020 as compared to the same period in the previous year. The visitor arrivals to Sarawak in 2020 declined by $97 \%$ compared to 2019 .

The pandemic impact has disrupted not only travel and tourism industry but also it has affected all sectors of human life from increase death rates in all age groups, unemployment, socio-economic impacts, mental health issues, overwhelming increase in poverty level. In addition to that, Covid-19 has altered people's way of life dramatically. There has been a drastic transformation in our social interactions, professional life and usage of digital technology. Now-a-days wearing a mask is a norm in our daily life. In a nutshell, the Covid-19 pandemic has profoundly impacted human capital, the way we live and lifestyle, learning, basic well-being, and future productivity. Davis (2020) indicated that, the COVID-19 pandemic has devasted the world, resulted an astonishing socio-economic turmoil in the societies around the world. According to UNWTO, the strict travel restrictions and lockdowns around the globe harshly obstructed tourism since the outbreak of the COVID-19 (UNWTO Tourism Barometer, Nov.2021).

The pandemic outbreak badly hit this service sector industry due to weaker economy, high unemployment, movement control and travel bans. Because of this virus outbreak, millions of jobs are at risk which had affected the SMEs, women and youth. The lockdowns, travel bans, economic crisis and the unemployment issues due to Covid-19 leads to an alarming stage face by all the countries in the 
world. Indeed, the travel and tourism industry has been critically impacted and is still continuing after nearly 2 years. The international tourism completely halted in April and May 2020, as more than 150 destinations around the world closed their borders and travel restrictions imposed by countries affected $80 \%$ of the international arrivals. According to UN Department of Economic and Social Affairs (2021), this pandemic is disrupting global supply chains and international trade. With nearly 100 countries closing national borders during the past month, the movement of people and tourism flows have come to a screeching halt.

\section{Tourism landscape due to COVID-19 - current scenario}

The international tourists flow during first half of 2021 showed that, the tourism industry has moderately rebounded because of the boosting results in the third quarter of 2021 especially in Europe. In July - September 2021 the international tourists' arrivals (overnight visitors) increased by 58\% as compared to the same period in 2020 (UNWTO World Tourism Barometer, November 2021). International Air Travel Association (IATA)'s air passenger market analysis revealed that, the recovery of global air travel is slowing in October 2021 with industry-wide revenue passenger-kilometres (RPKs) i.e., decline of 49.4\% as compared to the same period in 2019 level (IATA Economics, Oct.2021).

UNWTO showed the current scenario of international tourists arrivals in response to COVID-19;

Figure.1.1. International tourist flows comparison Jan- Sept. 2019 vs.2020vs.2021

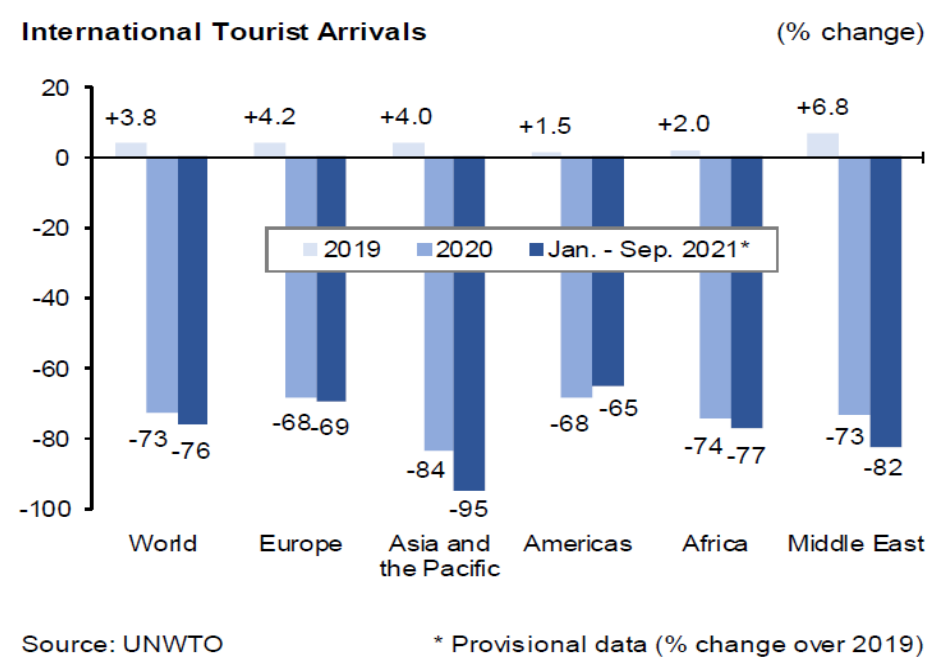

(Source: UNWTO World Tourism Barometer, Nov.2021)

The above data from UNWTO revealed that, in Asia-Pacific region the international tourists' arrivals decline 95\% in the third quarter of 2021 as compared to 2019. This is because many destinations continued to be closed for non-essential travel. Globally, the pace of recovery remains slow and uneven due to different degrees of mobility restrictions, vaccination rates and traveller confidence.

\section{Covid-19 Impact on the tourism business sector}

The tourism and travel industry business has heavily been impacted by this pandemic. Many tourisms related businesses were forced to close on a temporary basis and some businesses are allowed to re-open but with limited activity. This temporary or permanent closure of tourism or travel related business sector leads to a shocking escalation of unemployment. Chinazzi et.al and Murray (2020), the lockdown has slackened different economic sectors in the tourism and related industry. Sheller (2020) stated that, in India the movements are ceased within and outside of the country, it has directly affected the transportation sectors such as aviation, railways and other modes of transportation. This situation has a crushed in the hospitality industry. The MICE sector also has been affected by the pandemic. The business meetings and conferences were suspended and some were postponed. Majority of the meetings and conferences are done virtually which had caused huge reduction of activities related to the hospitality and tourism industry (Higgins-Desbiolles, 2020).

The goal of this paper is to elucidate how the Covid-19 impact affected the tourism business sector of Sarawak from the perspectives of tourism business stakeholders in the state. This study also illustrated the Government's initiatives to recover the tourism business sector and the innovative approach to rebuild the travel and tourism business industry in Sarawak, Malaysia. This research further extends to analyse Sarawak tourism industry partners perceptions towards Sarawak Tourism Board's 3R strategy to rebuild and recover Tourism Business Ecosystem (TBE) in the state. Finally, this research has given the strategic marketing directions for destinations to market and promote destinations during the post-covid19 period. The guidelines for the new norm travel and the way forward to overcome the critical issues during crisis time. There had been no studies conducted in Sarawak regarding the Covid-19 impact towards the tourism business sector from the perspectives of tourism stakeholders and Sarawak Tourism Board's (STB) 
rebuilding and recovery programmes to uplift the tourism industry. Hence this study is topical importance for planners and policy makers to get to know the pandemic impact towards tourism business and to understand the ways to overcome the crisis situation.

\section{Study Area}

Sarawak state, known as the "Land of Hornbill" is the largest state in Malaysia selected as the study are for this research. The total land area of Sarawak is 124,450 square kilo meter This state is located in the Island of Borneo bordering with the neighbouring countries such as Indonesia and Brunei. The state is made up of a total population of 2.8million in 2019 (Tourism Quick Facts 2020, Sarawak). The State has higher younger population with 1.25million population in the age group of 15-39 years old and 46.4\% of the population are employed in multiple sectors. The dispersion of the population consisted of 59.9\% of the people living in urban areas and $40.1 \%$ are living in rural areas of Sarawak. (Economic Planning Unit, Sarawak 2020).

Figure 1.2. Map of Sarawak

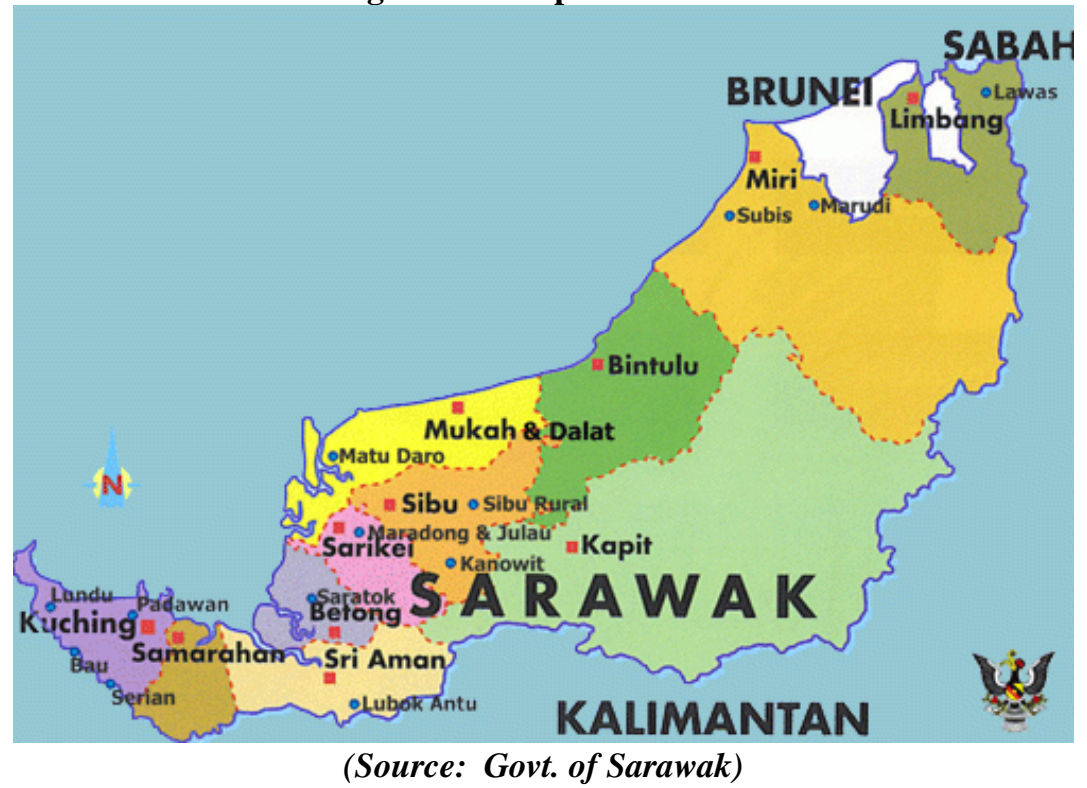

According to Department of Statistics, Malaysia (DOSM), the service sector is the main economic sector in Sarawak and the contribution of service sector to the state economy made up to 35.8\%. The contribution of agriculture was only $12.1 \%$ (DOSM,2020 \& EPU, Sarawak 2020). The service sector includes tourism and hospitality sector. This sector provided $19.1 \%$ share to the total employment in Sarawak (Tourism Satellite Account, Sarawak 2018). The GDP contribution from service sector to the state economy was $8.72 \%$ (Tourism Quick Facts Sarawak,2019).

There are a total of 12 districts in the state of Sarawak. From this, 3 districts had been selected for the study based on the highest number of tourists arrivals and tourism related business operations. The districts selected were, Kuching (capital district of Sarawak), Miri and Sibu.

\section{Sarawak visitor arrival trends due to COVID-19 pandemic}

The visitor arrivals to Sarawak from January to June 2021 was recorded at 64,767 visitors. There has been a drastic decline of 93.26\% as compared to the same period last year $(961,256)$. In 2020, Sarawak received a total of 1.19 mil visitors with a significant reduction of $74.27 \%$ as compared to the visitor arrivals of 2019 i.e.4.66mil (Dept. Of Immigration Sarawak). This trend revealed that the Covid-19 pandemic had badly affected the visitor arrivals to Sarawak. The movement of control order (MCO), lock-downs, flight suspension and border closure had directly affected the visitor arrivals and the tourism business sector as well. In terms of tourism receipts in 2020, Sarawak received Ringgit Malaysia (RM) 2.88billion with a decline of $75.10 \%$ from the tourism revenue in 2019 which was RM11.57billion (Tourism Quick Facts,2020). During the period Jan-June 2021, the state received tourism revenue RM 150.10 million with a decline of $93.58 \%$ as compared to the same period in 2020 (RM2.34billion) (Ministry of Tourism, Arts \& Culture, Sarawak June 2021). This whole scenario indicated that the COVID-19 impact disrupted and shattered the tourism and hospitality sector of Sarawak.

Table.No.1.1. Visitor arrivals to Sarawak 2016-2020

\begin{tabular}{|l|l|l|}
\hline \multicolumn{3}{|l|}{ Sarawak tourism performance 2016-2020 } \\
\hline Year & Number of visitors & $\%$ change $(+/-)$ \\
\hline 2016 & $4,661,100$ & $3.19 \%$ \\
\hline 2017 & $4,856,888$ & $4.20 \%$ \\
\hline
\end{tabular}




\begin{tabular}{|l|l|l|}
\hline 2018 & $4,430,921$ & $-8.77 \%$ \\
\hline 2019 & $4,662,419$ & $5.22 \%$ \\
\hline 2020 & $1,199,872$ & $-74.27 \%$ \\
\hline
\end{tabular}

(Source: Dept. of Immigration, Sarawak)

The visitor arrival data revealed that pre-COVID-19, Sarawak received an average of 4.6million visitors per annum. The COVID19 impact had badly affected the visitor arrivals to the state.

Diagram 1.3. Quarterly comparison (Jan-Sept.) of visitor arrivals to Sarawak 2019-2021

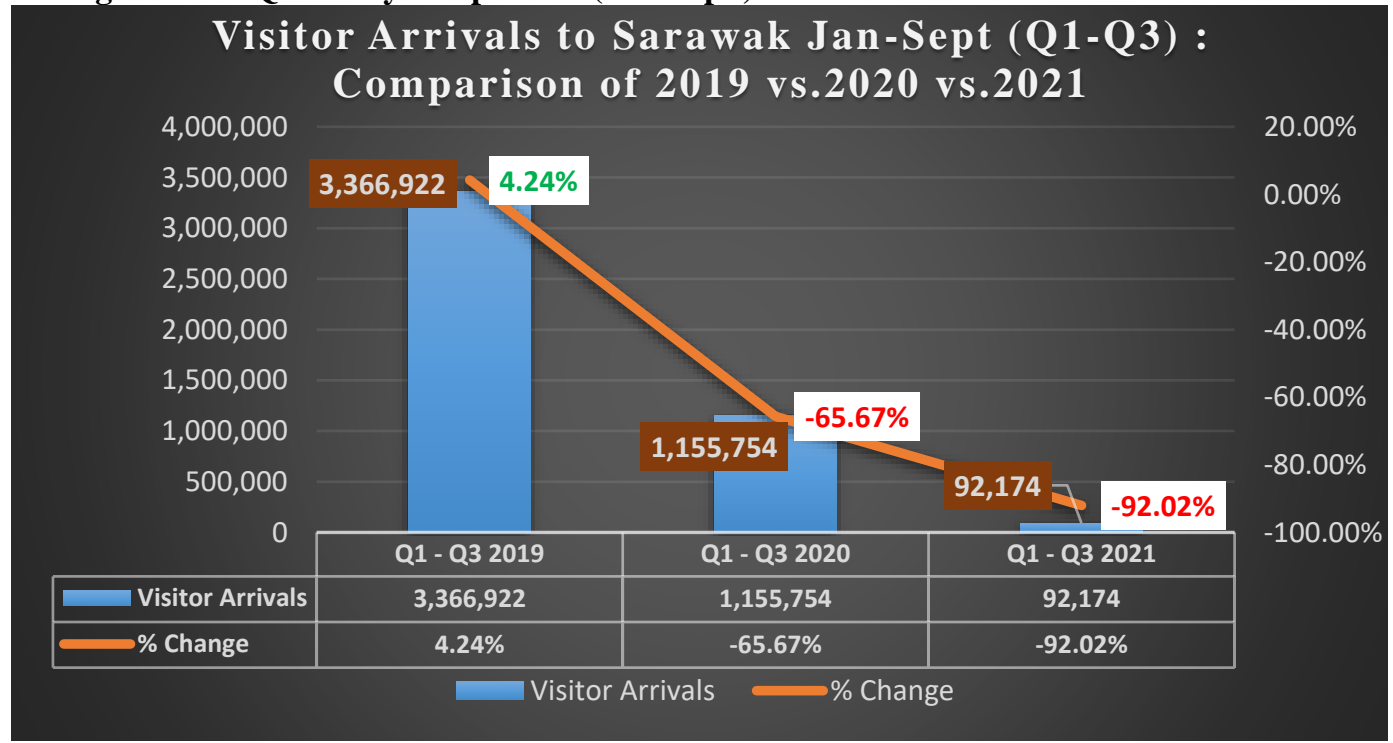

(Source: Dept. of Immigration, Sarawak)

The first quarter comparison of Sarawak visitor arrivals during the period 2019 to 2021 showed that the worse scenario of COVID19 impacts towards the visitor arrivals to the state. It was a sharp decline from $1^{\text {st }}$ quarter $2020(-19.12 \%)$ to $1^{\text {st }}$ quarter 2021 i.e., $96.34 \%$

\section{The COVID-19 impact towards the accommodation sector}

The pandemic impact severely affected the hotel industry in Malaysia and Sarawak. The data regarding the Average Occupancy Rate (AOR) from Tourism Malaysia revealed this scenario,

\section{Diagram 1.4. Hotel Average Occupancy Rate (AOR) 2016-2020 Malaysia vs. Sarawak}

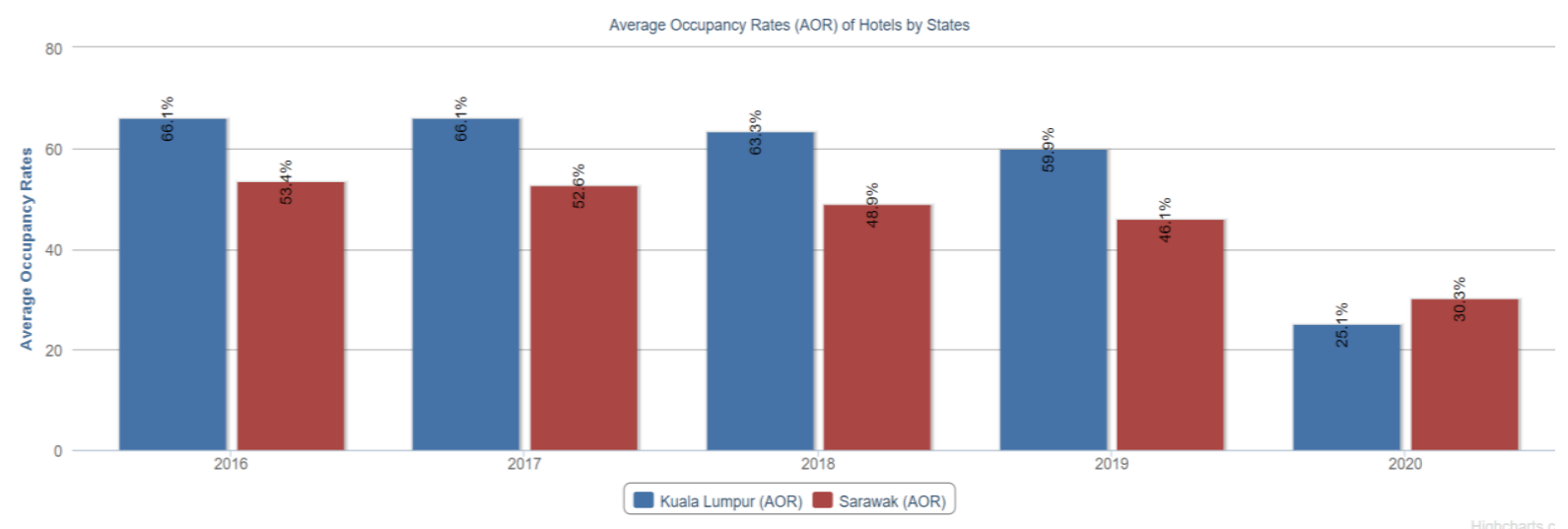

(Source: Hotel Survey, Tourism Malaysia)

The AOR showed that, in 2020 both Malaysia and Sarawak experienced very low occupancy i.e. Malaysia 25.1\% and Sarawak $30.3 \%$ compared to previous year's performance.

\section{$\underline{\text { Sarawak Tourism Board (STB) }}$}


Sarawak Tourism Board (STB) is the marketing agency under the Ministry of Tourism, Arts and Culture (MTAC) Sarawak. The main objectives of STB are to increase in tourist arrivals to the state via promotion, marketing and publicity of Sarawak both regionally and internationally and to position Sarawak as a prime destination for culture, adventure, nature, food and festival-based tourism. STB is the front liner of Sarawak tourism marketing and it has a strong collaboration with tourism industry players in Sarawak.

The COVID-19 had crippled the tourism business sector of Sarawak. The first lockdown was announced in Malaysia in March 2020. All tourism business and related industrial activities were stopped from there onwards. In April 2020, STB had conducted a feasibility study to know the covid-19 impact towards Sarawak's tourism business sector in Sarawak from perspectives of local tourism industry players. The findings of the study showed that, $91 \%$ of tourism business stopped because of heavy cancellation of tour packages. $60 \%$ of consumers cancelled their pre-booked tour packages. The impact towards the accommodation sector indicated that, all room bookings are cancelled and it had affected $100 \%$ on hotels and its operations. This leads to critical unemployment issues with many of the hotel staffs become jobless due to the incapability of continuing to pay salaries. The SMEs affected very critically. People working in this sector have no income due to no product sales. Local SMEs who are running its operation in conventional way, failed to forge ahead because of their absence in the digital space. No business for rural artisans/communities since there are no orders (STB Stakeholder Survey Report, April 2020). Based on this preliminary study findings and recommendations, the Ministry of Tourism, Arts and Culture (MTAC) Sarawak and STB created stimulus packages. STB has taken its initiatives in overcoming the pandemic impact to help boost the Tourism Business Ecosystem (TBE). The Board has implemented the 3R strategy in 3 Phases. The Phase 1 Rebuilding \& Relief, Phase 2 Recovery Collaboration and Phase 3 Redialling. Sarawak Tourism Board's 3R strategy underlined data driven insights. In line with that, STB had conducted this study among the Sarawak tourism industry partners to get to understand the pulse of the tourism industry business in Sarawak and to identify the effectiveness of STB's 3R strategies and initiatives to uplift the tourism industry players confidence.

\section{REVIEW OF LITERATURE}

This section focuses on the reviews of relevant theoretical and empirical findings of the COVID-19 impact towards tourism industry.

\section{COVID-19 impact towards tourism sector}

The impact of COVID-19 had affected all sectors of the economy such as tourism, service, trade, transport and every other field with vulnerable economic shocks. Tourism has been very badly affected by the COVID-19 pandemic crisis (Maria Zoi Spanaki et.al,2021). The uncertainty and fear of pandemic, the firms are under poor economic conditions, due to travel bans and cancellation of events and the prohibition of mass gatherings had affected badly the tourism and related service sectors (Horowit, 2020 and Elliot, 2020). This pandemic is considered as a health-crisis which had adversely affected the tourism and hospitality industry. According to Liu et.al (2016), when a health-related crisis emerged, tourists risk perceptions seem to be affected unfavourably. This kind of crisis had a profound impact on international travel and domestic travel and tourism marketing and related activities because people stop travelling to the infected areas to reduce the risk of contamination (Melly and Hanrahan, 2020). The fear of the Covid-19 virus spread forced the cities on lockdowns and left streets deserted in many countries (So Young Baea and Po-Ju Changb, 2021). In UK, 75million jobs were at risk due to Covid-19 pandemic impact because of more than $30 \%$ reduction in the tourist arrivals to the country (Stimac et.al,2020). The accommodation sector faced the biggest challenges due to this pandemic. This pandemic associated hygiene measures and travel restrictions adversely affected the financial system. The imposition of travel and related restrictions had caused the hotel industry collapsed and many hotels closed until further notice (Sharma and Nicolau,2020). As a result of Covid-19 the hotel sector in USA, the total employment hours drastically had decreased by $71 \%$ and the employee termination from hotel sector within two weeks increased by $470 \%$ because of lay-offs and hotel closures (Ross, 2020). According to Bakar and Roshi (2020), in China 75\% of the hotels closed because of the tourist arrivals decline and cancellations of booking. They further stated that, in Australia, the earnings from tourism had dropped by $50 \%$ on year-on-year and in Europe the receipts from hotels declined $95.2 \%$.

\section{Aviation industry trends due to COVID-19 pandemic impact}

According to International Air Travel Association (IATA), in 2020 brought an unprecedented challenge to the airline industry because of the closed borders, strict travel controls, and depressed travel confidence due to the worst scenario of the Covid-19 pandemic. RPKs (Revenue Passenger Kilometer) in 2020 showed a dramatic decline of $76 \%$ compared to 2019. In March 2021, the industry-wide revenue passenger-kilometers (RPKs) were 67.2\% lower compared to the pre-crisis level March 2019 (IATA Economics, Mar.2021). IATA measured that, global passenger air traffic dropped by $61 \%$ during the period January-October 2021 as compared to the same period in 2019. The latest trend showed that, the air travel demand increasing gradually in October 2021 measured in revenue passenger kilometers. This is because of the intensive vaccine roll-out and reducing air travel restrictions. 
Diagram 2.1. Aviation industry trends due to Covid-19 pandemic Performance varies also across int'I markets Cross-border travel restrictions remain the key driver

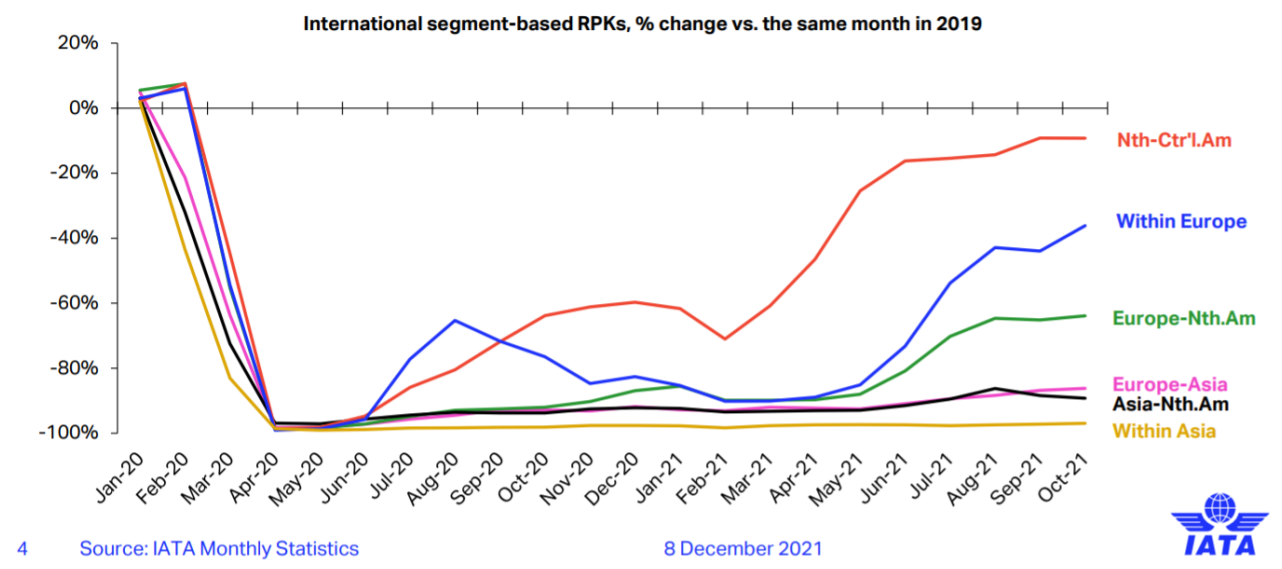

In Malaysia, the travel bans due to COVID-19 and low travel demand around the world have affected the major airlines such as Malaysia Airlines, Malindo Air and Air Asia. The airline operators started salary cut of its employees range from 10\% to 100\% and unpaid leave depending on salary range and position (Lee-Peng Foo et.al, 2020). Stimac et.al (2020), London Heathrow airport had a severe decline in the passenger traffic which exceeded $50 \%$ in 2020.

\section{COVID-19 impact towards tourism sector of Malaysia and Sarawak}

In Malaysia, the COVID-19 pandemic had hit the tourism industry hard. It is visible in terms of tourists' arrivals. In 2020, the country received 4.33 million tourists with a sharp decline of $83.4 \%$ as compared to 26.1 million in 2019 . The tourism receipts declined by $85.3 \%$ compared to 2019 (Tourism Malaysia, 2021).

The $1^{\text {st }}$ half year of 2021 (Jan- June2021) the tourists' arrivals to Malaysia were 50,673 was declined 98.8\% compared to the same period in 2020 where Malaysia recorded a total of 4,252,997 tourist arrivals. In terms of excursionist arrivals, the first half year of 2021, Malaysia received a total of 138,309 excursionists which was $91.9 \%$ decrease compared to the same period in 2020, the number of excursionists were 1,712,140. In terms of tourism revenue, during Jan-June 2021 recorded a decline of 99.4\%, Malaysia received RM 80.20mil while in Jan-June 2020 it received RM 12,572.30mil (Strategic Planning Division, Tourism Malaysia, Sept.2021).

Figure. 2.2. Tourism performance in 2020 Malaysia vs. Sarawak

Tourism Malaysia - Performance $2020 \quad$ Sarawak - Tourism Performance 2020
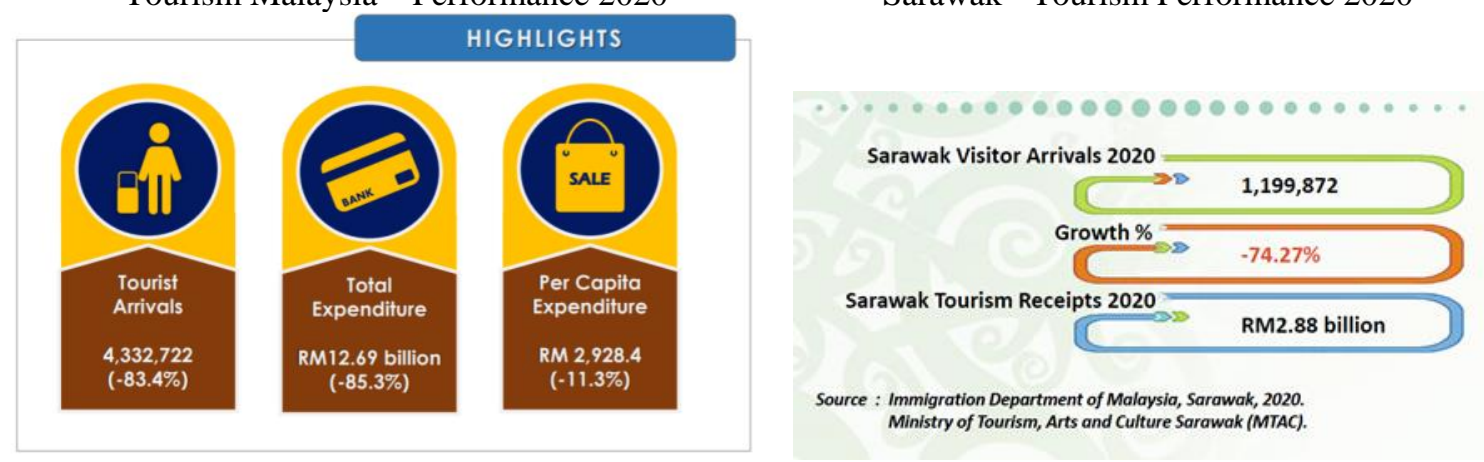

In the year 2020 the tourists' arrivals to Malaysia showed that, there was a dropped of $83.4 \%$ and a loss in revenue of $85.3 \%$ (Strategic Planning Division, TM 2021). In the case of Sarawak, the visitor arrivals decline in 2020 was $74.27 \%$ and the tourism receipts plummeted by $75.54 \%$ (Sarawak Tourism Quick Facts 2020). The details as below in the graph; 


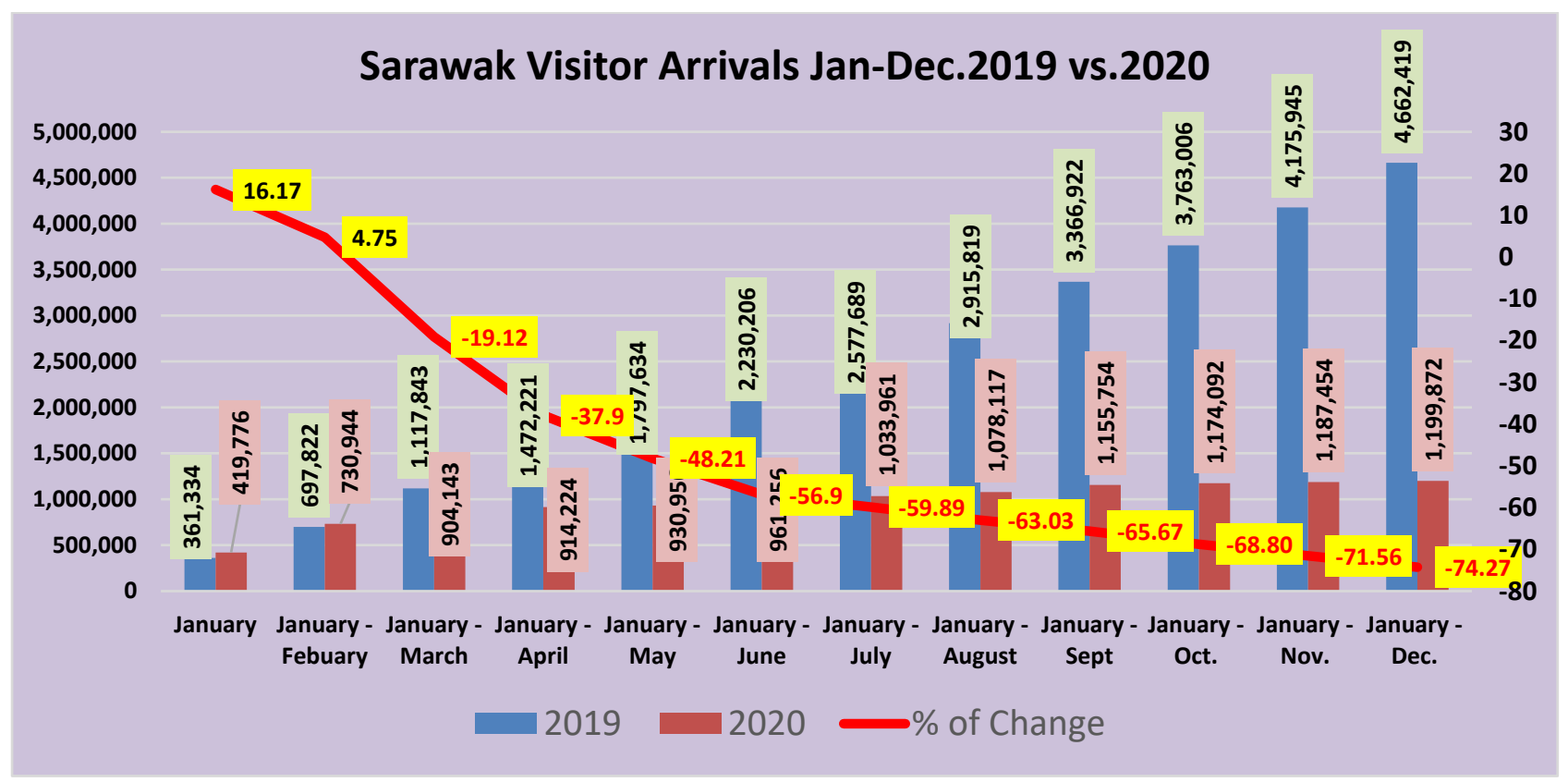

(Source: Dept. of Immigration, Sarawak)

\subsection{Tourism recovery and rebuilding programmes to regain tourism business}

The tourism and hospitality stakeholders need a collaborative guidance of overcoming this kind of pandemic crisis. Hence, a dynamic crisis management model and adopt high-technology tools for the industry recovery (Bin Li et.al, 2021). The UK Government interceded by contribution through financial assistance of up to 25,000 pounds for small tourism businesses and credit lines exceeding $£ 1 \mathrm{~m}$ for qualifying small and medium sized tourism enterprises (Stimac et.al.2020).

\section{METHODOLOGY}

Qualitative methodology was applied in this research to gather necessary information from the respondents. The data collection was conducted in Dec. 2020 -Jan.2021 at the three main districts in Sarawak i.e. Kuching, Miri and Sibu. The respondents are from different segments of tourism industry in Sarawak, consisted of tour operators or travel agents, people from accommodation sector, transportation providers, tourism product owners, MICE or event sector, handicrafts/SMEs, restaurant owners and others who are indirectly involved in tourism sector.

\subsection{Instrument and sampling frame}

The data was gathered by a self-administrated structured interview checklist. The interview questions included both closed ended questions \& subjective questions. The main contents include organizational information of the respondent, Covid-19 impact towards the tourism business and current situation, opinion about state governments recovery and rebuilding programme, tourism industry players level of support, their confidence and satisfaction of Government's and STB's rebuilding and recovery programmes and finally stakeholders' expectations to rebuild the tourism industry in Sarawak. In addition to that, these questions are related to tourism stakeholders' expectations and main attributes to build up their tourism business in Sarawak, the tourism industry partners key opinion to make Sarawak tourism to be more active and vibrant and finally to gather their suggestions regarding the ways to enhance consumer confidence level to travel without fear. Purposive sampling was used to select the respondents. There are a total of 85 respondents participated in the study. The sampling frame as below;

Table No.3.1 Sampling Frame

\begin{tabular}{|l|l|l|}
\hline Districts & Frequency (N) & \% \\
\hline Kuching & 47 & $55.3 \%$ \\
\hline Miri & 18 & $21.1 \%$ \\
\hline Sibu & 20 & $23.5 \%$ \\
\hline Total & $\mathbf{8 5}$ & $\mathbf{1 0 0 \%}$ \\
\hline
\end{tabular}


The highest number of participants are from Kuching district. This is because Kuching is the Capital of Sarawak and is also the main tourist spots in Sarawak. Hence, a significant number of tourism industry partners are the participants from this city. The samples are segregated based on the type of businesses.

Table. No. 3.2. Respondents' categorization based on type of business

\begin{tabular}{|l|l|l|}
\hline Type of business & $\mathbf{N}$ & $\mathbf{\%}$ \\
\hline Tour operators/ travel agents & 45 & $52.9 \%$ \\
\hline Tourism product owners & 1 & $1 \%$ \\
\hline Accommodation sector & 23 & $27 \%$ \\
\hline Transportation providers & 2 & $2.3 \%$ \\
\hline Handicrafts/SMEs & 6 & $7 \%$ \\
\hline Events/MICE sector & 5 & $5.8 \%$ \\
\hline Airlines & 3 & $3.5 \%$ \\
\hline
\end{tabular}

The above table revealed that the tourism stakeholders are from different segments from the industry. The highest percentile (52.9\%) are tour operators or travel agents followed by accommodation sector (27\%) who had participated in the interview session. Due to the pandemic situation, the interviews were done with strict SOPs and also data were gathered through telephone interviews as well. For some respondents, the interviews were done through digital platforms.

\section{DATA ANALYSIS AND RESULTS}

This part consisted of the analysis based on the objectives of this research. The first session analysed the industry players' perception regarding COVID 19 impact (MCO \& related lockdowns) towards their business. The next session tried to identify tourism industry partners awareness, industry's confidence level, industry support and satisfaction towards state government recovery and rebuilding programmes and specifically focus on industry response towards STB's 3R strategy initiatives to boost Sarawak's Tourism Business Ecosystem. The next session explained the tourism industry players' expectations towards STB's tourism recovery and rebuilding programmes. the stakeholders' overall opinions about the ways to increase consumer confidence level and the future programmes to rejuvenate Sarawak Tourism.

\subsection{Impact of COVID19 towards tourism business sector of Sarawak}

Throughout the interview sessions, a significant number of tourism industry partners revealed that there was a drastic decline (77.1\%) in tourism related business and lack of income $(51 \%)$ to operate tourism business. Hence, the industry became inactive. The respondents revealed that, their customers were not interested to make trips because of the fear factor related to the virus contamination about travel (45.8\%). The major challenge they are facing is the frequent cancellation of tour packages (49\%).

Figure. 4.1. COVID-19 impact towards Sarawak Tourism business sector

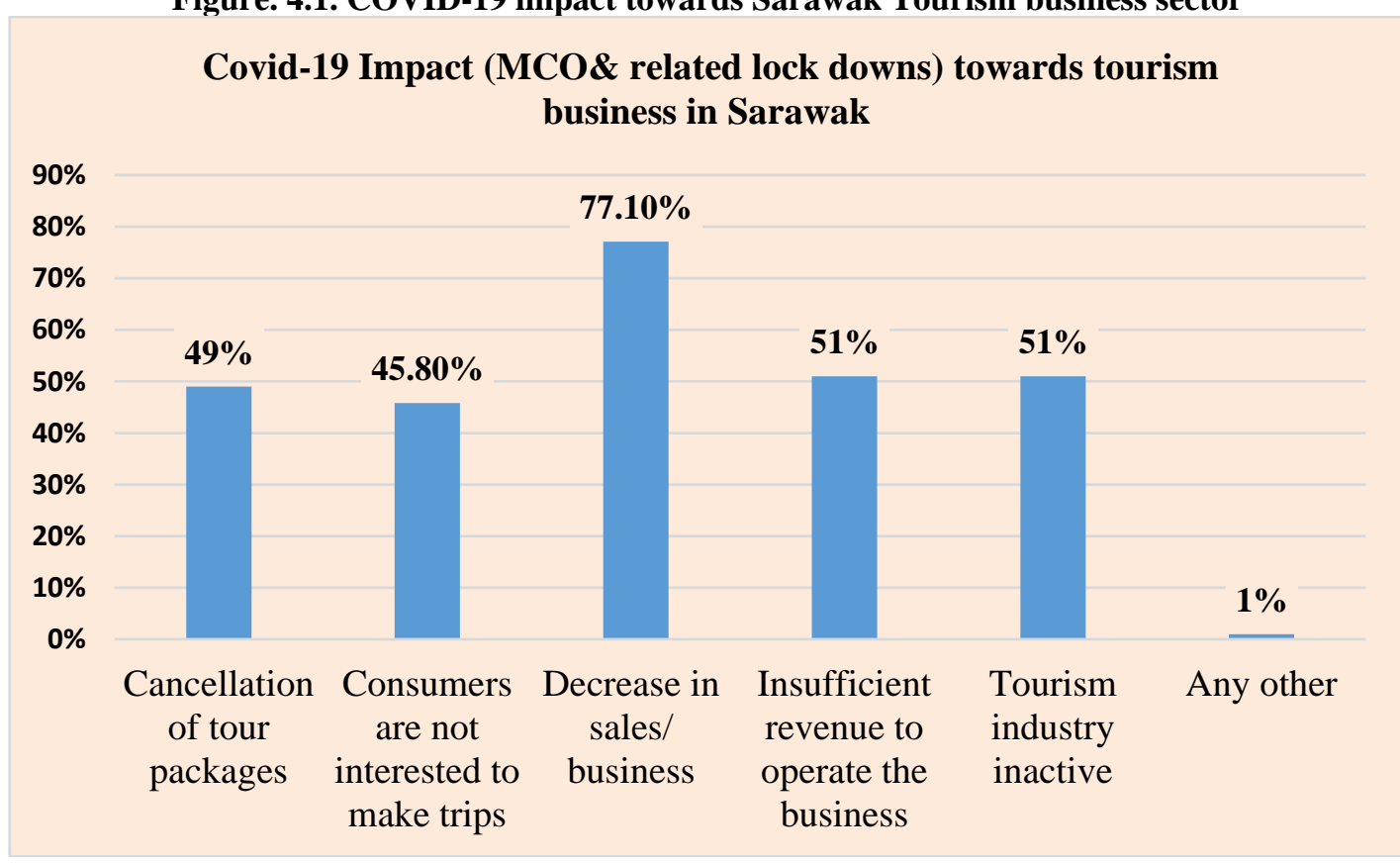


The industry partners responses regarding the Covid-19 impact towards tourism business are,

"Company cash flow keep on reduce, no earning instead of keep on expense for business operation. We are going through a tough time because of refunding for the previously booked online tours so that no business and cash outflows due to refunds" (Travel agent, Sarawak)

"Due to frequent cancellation of flights, the flight schedule, travellers trip cancellation \& state policy on Compulsory Quarantine significantly reduce the number of visitors coming to Sarawak" (Tour operator, Sarawak).

"Loss of income from tourism related business. Customers cancelled the trip and the staffs working in travel agencies/ tour companies forced to work on shift basis and it affected the wages" (Travel agent, Sarawak).

The covid-19 impact badly affected in hotel and MICE sector. The respondents stated that,

"The hotel rooms are empty and very low occupancy rate in hotels due to less number of tourists. This condition leads to loss in our hotel revenue and the accommodation sector is struggling to survive due to the pandemic hit. The jobs in hotel sector are under high risk and we are very much worried about the sustainability of hotels in near future" (Accommodation sector, Sarawak).

All events are going to full virtual and the physical events are cancelled affect the MICE sector in Sarawak. (Event organizer, Sarawak)

\subsection{The current situation in tourism business sector after the implementation of govt. recovery and rebuilding programmes}

The Chief Minister of Sarawak had announced financial relief assistance for tourism sector to revitalize tourism industry. The relief assistance is known as "Bantuan Khas Sarawakku Sayang" (BKKS) with a total of RM 1.154 billion financial assistance for tourism sector. The financial packages were implemented for revitalizing the tourism industry. Under this BKKS 3.0, the relief assistance is, $25 \%$ discount on assessment rates, $30 \%$ discount for land rent, deferment of land premiums, discount of utilities bills, waiver of hotel license fees for 2020, interest free Micro-Credit Scheme for eligible SMEs, 6 months interest free soft loan, an one off cash assistance of RM600 to RM 959 licensed van operators, RM1,976 for taxi drivers and RM 739 school bus/van operators in Sarawak. In addition to that, offering hotels as temporary quarantine centers, one-off RM 500 special grant to boat operators and one-off RM 1,500 special grant to tour guides / national park guides in the state. Another monetary assistance provided under BKKS 3.0 is RM500 one-time cash payment to owners and operators of passenger boats (www.sarawak.gov.my, 2021).

Table. No. 4.1. Tourism stakeholders' response towards Govt. recovery \& rebuilding programmes

\begin{tabular}{|l|l|}
\hline Sarawak tourism stakeholders' response & \% \\
\hline Re-open business \& we are happy to the relief assistance & $41.70 \%$ \\
\hline Continuing engage with consumers and encourage them to make trips & $39.50 \%$ \\
\hline Receive Govt. support to recover business & $35.40 \%$ \\
\hline The tour package sales/ business start to pick up & $17.10 \%$ \\
\hline Govt. prepared new policies \& SOPs to ensure safe travel in Sarawak. & $57.30 \%$ \\
\hline
\end{tabular}

The analysis revealed that, the economic stimulus packages offered by the Sarawak government, the responses from tourism industry partners are more optimistic for doing the tourism business. 57.3\% revealed that, the government new policies and COVID-19 SOPs (Standard Operating Procedure) make Sarawak a safe travel destination. 42\% have continuous engagement with their consumers and gave them encouragement to make trips to Sarawak. 39\% of tour operators and travel agents started to re-open their business. Almost $35.4 \%$ of the industry partners stated that they received government support to recover business. Hence, they started to re-open their tourism business and almost $17 \%$ of the respondents mentioned that their businesses start to pick up. The licence of tour and park guides, Ministry of Tourism, Arts and Culture, Sarawak had provided a fee subsidy on tour guide licences in the year 2020. These initiatives and economic stimulus packages had given a push in the tourism business eco-system.

\subsection{Awareness about STB's tourism recovery and rebuilding programmes-3R strategy}

STB had implemented a 3R strategy in the year 2020 with an aim to rebuild Sarawak tourism business ecosystem and to support the tourism industry players to recover and rebuild their business, and to promote and market Sarawak beyond leisure tourism in alignment with the state's direction (Sarawak Tourism Board,2020). 


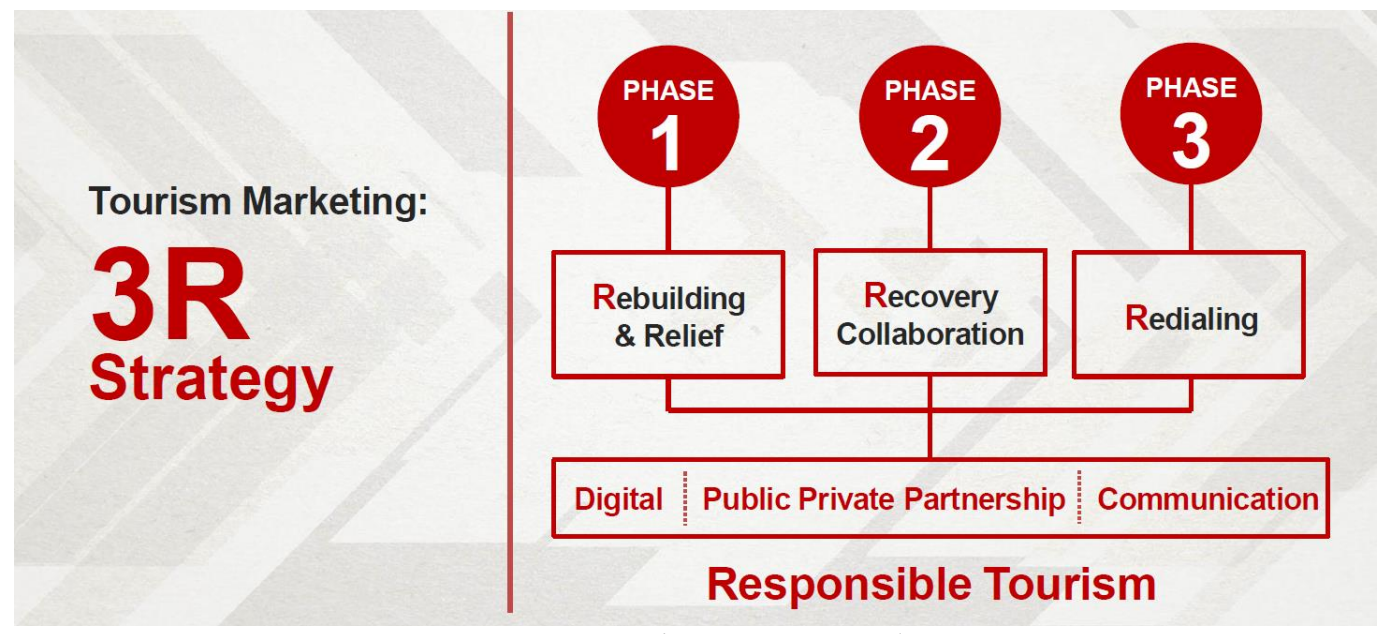

(Source: - Sarawak Tourism Board, 2020)

STB's 3R strategy based on responsible tourism and supported by three pillars such as digital platform, public-private partnership (PPP) and integrated communication. This $3 \mathrm{R}$ strategy has three phases which covers:

\section{Phase 1 - Rebuilding and Relief}

$>$ Sarawak Product Experience (SPE) :- To experience first-hand the various tourism products, to advocate Responsible Tourism awareness and educating the local community on Digital Footprint known as "Jejak Digital".

$>$ Sarawak Tourism Online Eco-System Fund: - Funding allocated by Sarawak Tourism Board to the tourism players as a catalytic programme to expand Sarawak Tourism's Digital footprint, in collaboration with Sarawak industry partners.

\section{Phase 2 - Recovery Collaboration}

$>$ Intra-state Campaign: - To boost the State's tourism efforts and activities. Sarawak Residents to enjoy 50\% OFF travel packages. A joint collaboration between Sarawak Tourism Board (STB) and Sarawak Tourism Federation (STF). The campaign aptly known as Sia-Sitok Sarawak (SSS).

$>$ Sia Sitok Accommodation: This programme is the joint collaboration with STB, Malaysian Hotel Association (MAH) Sarawak chapter and Sarawak tourism industry players. The aim of this programme is to get benefit to all sectors of tourism industry.

$>$ Sarawak Ambassador Programme: - Joint collaboration with Grab Malaysia, State Library and STB on an E-Learning modules on Tourism Products and Responsible Tourism Awareness under this programme for e-hailing drivers and local community at large.

$>$ Strategic Partnership Collaboration Fund: It serves a variety of purposes in supporting the industry players to kick off their marketing initiatives with new look.

\section{Phase 3 - Redialling}

$>$ Inter-state Campaign: - Focused on domestic travel and the campaign which is an extension of the Sia Sitok Sarawak - IntraState Package Campaign and a catalytic approach to incentivise the tour operators on the Visitors Incentive Package (VIP).

$>$ Visitors Incentive Package: - Incentives provide for Sarawak inbound tour operators with a registered trade company and licensed by Ministry of Tourism, Arts and Culture Malaysia (MOTAC) based on bringing visitors to the state.

\subsection{Level of Sarawak stakeholder's support, confidence and satisfaction towards STB's 3R Strategy}

A significant number of industry partners (92\%) are supportive of STB's 3R strategy to boost TBE. The analysis revealed that, Sarawak tourism industry stakeholders are delighted towards STB's initiatives. 
Figure. 4.2. Level of Sarawak tourism stakeholders' support

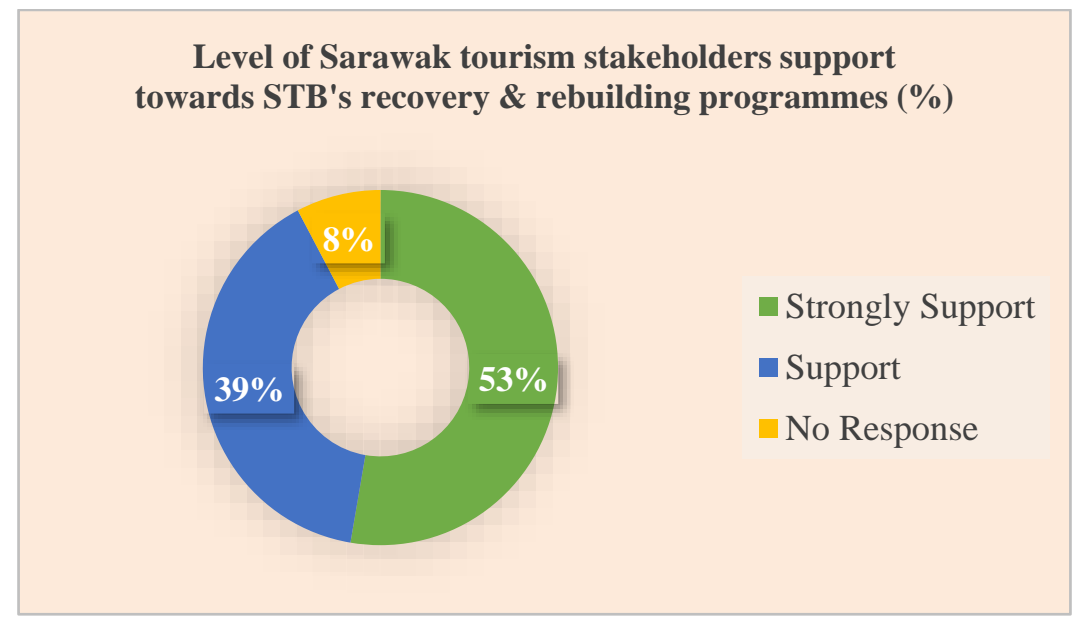

A significant number of industry players showed a high-level confidence (76.1\%) towards STB's 3R strategic initiatives towards the tourism recovery and rebuilding programmes. A higher percent $(80.2 \%)$ was satisfied with STB's overall initiatives to uplift the tourism industry.

Figure. 4.3. Sarawak tourism stakeholders' level of confidence

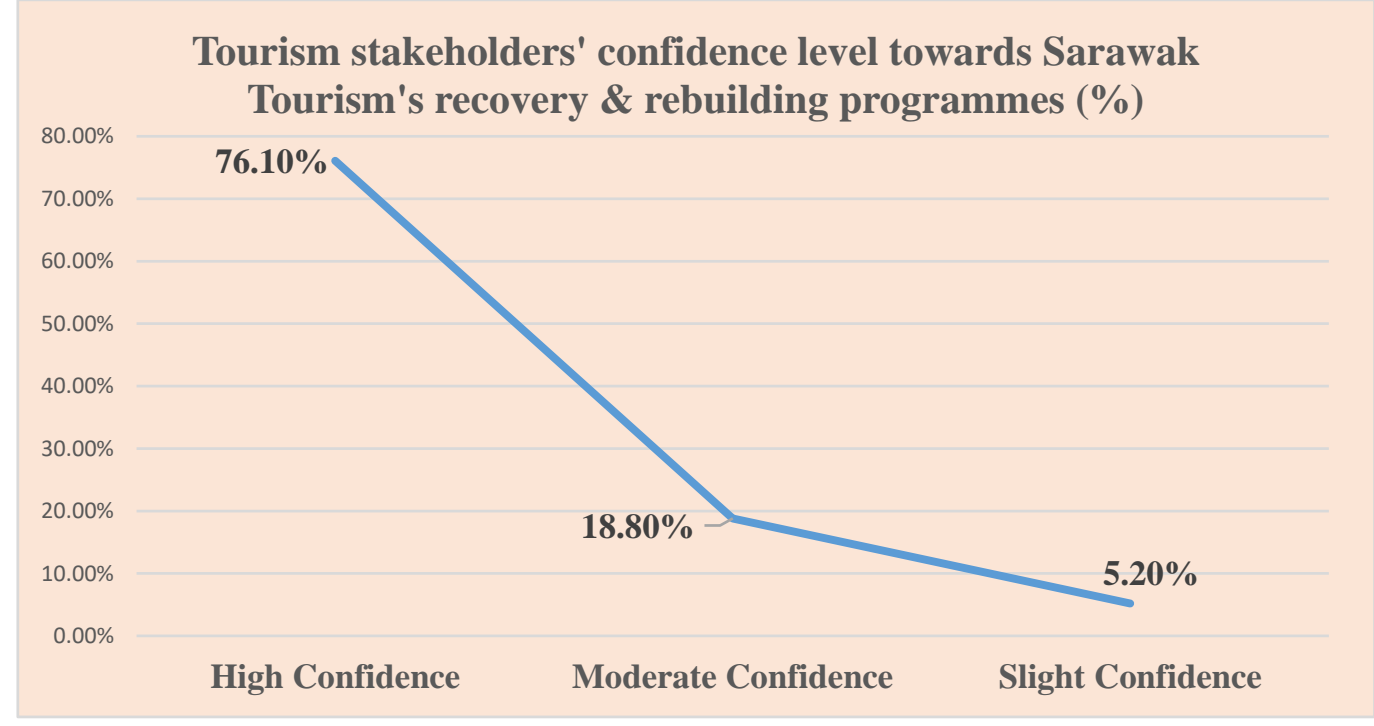

The industry partners responses during the interview were;

"The $3 R$ strategy of STB is a good initiative to elevate the tourism industry and we strongly agreed that the $3 R$ strategy ensures sustainability in Sarawak tourism" (Respondent from MICE sector).

"It is an innovative approach because training is given in tandem with the $3 R$ strategy and financial assistance in $3 R$ strategy assists the local community. Hence, I believe that this $3 R$ strategy will boost confidence of the local communities and in the way forward it has given positive results to Sarawak tourism" (Tour operator, Sarawak).

"The recovery and rebuilding programmes of STB has given a confidence to continue my business in travel and tourism sector" (A travel agent, Sarawak).

\subsection{Tourism stakeholder's expectations and important attributes to rebuild Sarawak tourism industry}

There are mix of responses regarding this aspect during the interview sessions. Based on their responses the main attributes analysed as follows; 
Table. No. 4.2. Tourism stakeholders' expectations to rebuild tourism industry

\begin{tabular}{|l|l|}
\hline Sarawak stakeholders' expectations & $\boldsymbol{\%}$ \\
\hline Create more niche products to attract visitors & $65.60 \%$ \\
\hline Aggressive marketing \& promotion (domestic) & $64.60 \%$ \\
\hline Skill development especially digital skills \& capacity building programmes & $54.20 \%$ \\
\hline Include tourism in state/national economic emergency packages & $43.80 \%$ \\
\hline Invest in partnerships (PPP) & $33.30 \%$ \\
\hline To include more activities inside tour packages so as to increase length of stay in Sarawak & $46.90 \%$ \\
\hline Promote domestic friendly tour packages & $63.50 \%$ \\
\hline Practice responsible and sustainable actions & $42.70 \%$ \\
\hline Aggressive use of digital marketing and promotion to promote destination & $49 \%$ \\
\hline
\end{tabular}

Based on the interview results it can be understood that Sarawak need to make more tailor-made packages for domestic market to cater to the needs of domestic tourists and their length of stay in Sarawak. In addition to that, the industry players suggested the importance of aggressive digital marketing and promotion is an integral part of tourism recovery. The quotes from the responses from industry players;

"We are waiting for the borders to re-open, airlines need to fly, and promotions need to focus on the key attractions to regain consumer confidence. Do not need more products. Need to regain market for products and attractions, we have to recreate our business as usual" (Travel agent, Sarawak).

"Support tour operators in recce and study the potential tourism products to make it become sellable packages in the market during the new-norm travel. In addition to that, better strategic effort and synergy between industry partners and government" (Travel agent association, Sarawak)

"wage support schemes are needed to protect jobs. Otherwise, there may not be many travel SMEs left by mid-2021 " (SME sector, Sarawak).

"Give cash vouchers to Sarawak residents to encourage them to travel locally. Voucher will encourage them to book tours and spend more locally to boost local tourism" (Tour operator, Sarawak).

\subsection{Key opinions to rejuvenate Sarawak tourism industry to be more active and vibrant}

This session explained overall opinions of Sarawak tourism industry players responses to make Sarawak tourism more aggressive, active and vibrant. According to the interview results from the respondents, they suggested many ways to improve tourism industry in Sarawak in a way that,

"To identify effective marketing \& advertising impacts i.e. digital (extensive inbound marketing), pop-up gimmicks at targeted locations, local organic content (broadcast / digital)" (Travel agent association, Sarawak).

According to them, to expand the series of tourism products and go in less-explored places in Sarawak. To identify best products and make it an attractive saleable package for the new norm travel.

"We must look new tourism products in Sarawak such as agro- tourism, volunteerism, event tourism, business events partnering with Business Event players on tourism activities" (owner of an event company in Sarawak).

The discussion with the industry partners again highlighted fruitful information towards Sarawak tourism industry to make a vibrant one. The responses pointed towards the importance of travel incentives provide to the tourists who are willing to visit Sarawak, the importance of digital marketing and promotion, use of KOL (Key Opinion Leaders) or influencers to promote Sarawak domestically and internationally.

"Flight services such as AirAsia give small local gifts or souvenirs to visitors as a thank you note for using their service and for coming to Sarawak during the new norm travel to make customers happy" (transportation provider, Kuching).

"Sarawak Tourism has to continue to promote the places of interest at Sarawak through roadshows or website or tv channel and increase facilities of places of interest to attract people" (Tourism product owner, Sarawak)

"Promote the hidden jewels of Sarawak. Develop proper facilities and amenities without compromising the beauty and natural ecosystem of the area" (Tour operator, Sarawak).

"Make Sarawak a place for family vacation. Create a family package more where older people can join" (Travel agent, Sarawak)

The respondents also indicated the importance of health and safety facilities in the destination. This is more important during the post pandemic period. All the respondents mentioned the importance of strict SOPs and safe environment in Sarawak to boost consumer confidence level.

"Ensuring health \& safety is a priority by each tourism supplier/provider" (Travel Agent Association, Sarawak).

"The government has to prepare a comprehensive SOP to follow so that people are able to have a peace of mind while travelling" (Accommodation sector, Sarawak). 


\subsection{Suggested ways to enhance consumer confidence level to travel without fear during post-pandemic}

This session the respondents explained about the importance of SOPs and the government procedures to control the number of Covid-19 cases in Sarawak. Sarawak with a huge land area and not densely populated in the state. This attribute has suggested by most of the tourism industry players. They mentioned that, the spacious geographical area is a positive aspect to promote Sarawak in key markets to convince the travellers to visit Sarawak without fear under "less crowded destination". Keep up to date information about the SOPs in Sarawak and the Covid-19 cases and vaccine roll-outs to all over Sarawak through digital platforms. From the tourism players point of view to enhance consumer confidence level as;

"Focus on being an "eco" destination with wide open spaces, remote locations (no crowd), booked out accommodations (home-stays, farm-stays, small hotels), high level of SOP for bigger hotels, concern for the environment (to balance the ecosystem and thus reduce pandemics and natural disasters) (sustainable tourism)" (Travel agent association, Sarawak).

"Keep them engaged with creative and regular communication - different forms such as email, digital programmes (talks, walk-throughs, virtual tours), physical mailers (VR goggles with a promo video, creative postcards, 'bits of Sarawak')" (MICE sector, Sarawak).

"Detailed SOPs to be displayed through digital media, together with pictorials \& videos to catch the attention of travellers" (Travel agent, Sarawak).

"Show open spaces and outdoor activities, with proper SOP. Emphasize sanitizing protocols, tighten control on safety, and follow SOP. Practice the new norm no matter what to attract consumer about the cleanliness and the safety of the location. Social media take part to promote more on awareness and programme" (Tour operator, Sarawak).

The industry partners indicated a lot of views regarding to attract consumers to Sarawak during the new norm travel.

\section{CONCLUSION AND RECOMMENDATIONS}

Tourism industry stakeholder analysis is an integral part of tourism planning and strategy development. The tourism industry business is embedded with active involvement of the stakeholders. Tourism's effectiveness is depending on considering stakeholders needs and requirements, the organisation must carry out some form of stakeholder analysis. It is a process whereby key stakeholders are identified and grouped according to levels of participation, interest and influence. As Covid-19 badly hit the tourism industry, and the stakeholders are striving to achieve the tourism industry back to normal. Hence, this research provides key information about the stakeholders' perceptions regarding Sarawak Tourism's overall performance in recovery and rebuilding, STB's initiatives in rebuilding the tourism industry, Govt. policies and programmes making Sarawak a safe destination and the way forward.

\section{RECOMMENDATIONS}

The main recommendations to rebuild the tourism industry and to revitalize the Tourism Business Ecosystem (TBE) in a destination during the new norm travel based on this research as,

\section{Focus on domestic market:-}

$>$ Intra-state marketing and promotion strategy: - marketing and promotion campaigns focus on local population in a state and encourage them to travel with discounted prices. The government and tourism industry players go hand-in hand to develop this strategy with attractive offer prices and give awareness to local communities to travel with in their state. This way boost staycation.

$>$ Inter-state travel marketing and promotion strategy / domestic travel:- Encourage the citizens travel with in the country. Intergovernmental efforts to create green-bubble travel between states to make sure safe travel between states. Follow strict SOPs in destinations. Develop domestic campaigns and design the campaign based on the new norm travel consumer behaviour and traveller demand as well.

$>$ Messages to encourage travellers to make trips: - Aggressive marketing promotion campaigns, media publicity through online and offline to encourage travellers to make holiday trips.

$>$ More domestic friendly tour packages (tailor-made domestic packages):- The trends of post-pandemic travel begins with domestic and regional travel in the near future. Hence, the destination marketing organizations (DMO) and tourism industry players make more attractive, exotic and safer domestic friendly tour packages to attract domestic travellers. Include varieties of activities and attractions in the tour itinerary. This will encourage them to buy the package and increase their length of stay in a destination simultaneously. This way both the destination and accommodation sector will be benefited.

\section{Rejuvenate and recharge}

$>$ Inspire travellers who are still dreaming and engage with them those who may be ready to travel with content and messaging.

$>$ By maintaining online presence, encourage industry partners to spend time in personal development and training by participating in webinars and talks organized by various parties in online.

$>$ To focus more on increasing destination visibility through digital platforms, connect with consumers, even create confidence among our partners and to reduce fear factor.

> Innovation must continue to push "Responsible Travel" that will ensure giving back to local communities and the environment. This will increase the people behavior and demand towards responsible travel during the recovery period.

\section{Strict SOPs, Hygiene and flexibility:-}


$>$ Information on SOPs, hygiene measures and pandemic protocols should be at the forefront of brand communications, supported by reservation flexibility or full refunds to provide travellers with peace of mind. This will motivate them to make trips.

$>$ Ensure the hotels, public transportations, the tourists spots are following strict SOPs and social distancing. To avoid overcrowding and follow strict visitor management in heritage and cultural monuments.

\section{Supportive digital content :-}

$>$ To use multiple digital channels to promote destination -including news media, travel sites and advertising — to share reassuring content, such as messaging and imagery on social distancing, temperature check-in, reduced capacity, contactless services, mask use, and hygiene measures. Covid-19 regular updates and related news publish in media.

\section{Public-private partnerships (PPP) and collaborations}

$>$ Government and industry players work closely for joint promotion and marketing the destination during the new norm travel. Joint investment for the destination development for the way forward.

$>$ Partnership campaigns with airlines, online travel agencies (OTA) and accommodation sector to boost destination visibility and for future travel.

\section{REFERENCES}

[1] Bakar, N. and Rosbi, S. (2020), "Effect of coronavirus disease (COVID-19) to tourism industry. International Journal of Advanced Engineering Research and Science, 7 (4), 189-193.

[2] Bin Li, Tingting Zhang et.al. (2021) A dynamic model of crisis management from a stakeholder perspective: the case of COVID-19 in China, Tourism Review, 124.

[3] Davies, W. (2020). The last global crisis didn't change the world. But this one could. The Guardian. March 24, 2020. https://www.theguardian.com/commentisfree/2020/mar/24/coronavirus-crisis-change-world-financial-global-capitalism.

[4] Department of Immigration, Sarawak State (2021). Visitor Arrivals to Sarawak. Government of Malaysia.

[5] Higgins-Desbiolles, F. (2020), "Socialising tourism for social and ecological justice after COVID-19. Tourism Geographies, 22 (3), 610-623.

[6] Horowit, J. (2020). The global coronavirus recession is beginning. CNN. Media report. Available at: https://edition.cnn.com/2020/03/16/economy/globalrecessioncoronavirus/

[7] Hubert G. Scarlett (2021). Tourism recovery and the economic impact: A panel assessment, Research in Globalization, 3 (2021) 100044 1-11.

[8] International Air Transport Association (IATA) (2021). Covid-19 weak year end for air travel and outlook is deteriorating. 1-11.

[9] International Air Transport Association (IATA) (2021). Air Passenger Market Analysis, October 2021.

[10] Lee-Peng Foo et.al. (2020), The impact of COVID-19 on tourism industry in Malaysia, Current Issues in Tourism, 1-12 https://doi.org/10.1080/13683500.2020.1777951.

[11] Maria Zoi Spanaki et.al. (2021). Tourism in the post(?) COVID-19 era: evidence from the hotel sector in the North East of England, Worldwide Hospitality and Tourism Themes, 1755-4217 DOI 10.1108/WHATT-01-2021-0013.

[12] Md Ozair Arshad et.al (2021). Understanding the impact of Covid-19 on Indian tourism sector through time series modelling, Journal of Tourism Futures, 1-15.

[13] Melly, D. and Hanrahan, J. (2020). Tourism biosecurity risk management and planning: an international comparative analysis and implications for Ireland. Tourism Review. 76 (1). 88-102.

[14] Pratt, S. (2015). The economic impact of tourism in SIDS. Annals of Tourism Research, 52 148-160.

[15] Ross, D. (2020), "The economic impact of COVID-19 on the hotel industry", Hospitality Technology, available at: <https://hospitalitytech.com/economic-impactcovid-19-hotel-industry> (accessed 3 October 2020).

[16] Sarawak Tourism Quick Facts (2020). Ministry of Tourism Arts and Culture, Sarawak, 1-22.

[17] Sarawak Facts and Figures (2020). Economic Planning Unit, Government of Sarawak 1-20.

[18] Sharma, A. and Nicolau, J.L. (2020), "An open market valuation of the effects of COVID-19 on the travel and tourism industry", Annals of Tourism Research, Vol. 83.

[19] So Young Bae and Po-Ju Chang. (2021).The effect of coronavirus disease-19 (COVID-19) risk perception on behavioural intention towards 'untact' tourism in South Korea during the first wave of the pandemic. Current Issues in Tourism, 24 (7), 1017-1035.

[20] Tourism Malaysia (2021). Facts and Figures Overview. Retrieved on March 30,2021 from Tourism Malaysia website: https://www.tourism.gov.my/statistics.

[21] Tourism Malaysia (2021). Hotel Survey Average occupancy rate of hotels Malaysia \& Sarawak , Tourism Malaysia. 2016-2020 http://mytourismdata.tourism.gov.my/.

[22] Tourism Malaysia (2021). Malaysia Tourism Performance Jan-Dec2020, Tourism Malaysia, http://mytourismdata.tourism.gov.my/.

[23] United Nations World Tourism Organization (UNWTO) (2021). Tourism suffers its deepest crisis with a drop of $74 \%$ in 2020 in international arrivals. UNWTO World Tourism Barometer Nov.2021 UNWTO Madrid (Spain): 19 (1), 1-13.

\section{AUTHORS}

First Author - Fency Sivadasan, Senior Manager - Research, Sarawak Tourism Board, Sarawak, Malaysia, Email:

fency@sarawaktourism.com

Second Author - Sharzede Binti Salleh, Chief Executive Officer, Sarawak Tourism Board, Sarawak, Malaysia, Email:

sharzede@sarawaktourism.com 
